DOI: https://doi.org/10.24127/ajpm.v8i3.2276

\title{
MUSEUM TIMAH INDONESIA PANGKALPINANG SEBAGAI ALTERNATIF PEMBELAJARAN MATERI SUDUT
}

\author{
Fitri Apriani' ${ }^{1}$ Putri Cahyani Agustine ${ }^{2}$ \\ ${ }^{1,2}$ Pendidikan Matematika, STKIP Muhammadiyah Bangka Belitung \\ E-mail: $\quad$ fitri.apriani@stkipmbb.ac.id ${ }^{l)}$ \\ putri.cahyaniagustine@stkipmbb.ac.id ${ }^{2)}$
}

Received 9 September 2019; Received in revised form 30 November 2019; Accepted 24 December 2019

\begin{abstract}
Abstrak
Tujuan penelitian ini adalah untuk mengetahui peran konteks Museum Timah Indonesia Pangkalpinang sebagai alternatif pembelajaran pada materi sudut. Penelitian ini menggunakan design research dengan menggunakan Hypothetical Learning Trajectory (HLT) dimana penelitian dilakukan dalam tiga tahap, yaitu desain awal, eksperimen pengajaran (pilot experiment) dan analisis retrospektif. Penelitian ini dilakukan di SD Negeri 29 Pangkalpinang. Data dikumpulkan yaitu dengan pre test dan post test, rekaman video, pengumpulan hasil siswa, wawancara, dan catatan lapangan. Hasil penelitian menunjukkan bahwa dengan konteks Museum Timah Indonesia Pangkalpinang, siswa dapat memahami pengukuran sudut. Siswa lebih tertarik dan termotivasi dalam menyelesaikan pengukuran sudut sehingga pembelajaran lebih bermakna. PMRI dapat digunakan sebagai pendekatan untuk belajar pengukuran sudut di sekolah dasar.
\end{abstract}

Kata kunci: Museum timah indonesia; PMRI; sudut.

\begin{abstract}
This aims of this study are to know the role of Museum Timah Indonesia Pangkalpinang context as alternative to understanding angles. This studi was using design research using Hypothetical Learning Trajectory (HLT) where research is conducted in three stages, namely initial design, teaching experiment (the pilot experiment) and retrospective analysis.this research was conducted at SD Negeri 29 Pangkalpinang. The data were collected through several things, namely by pre test and post test, video recording, collecting student work, interviews, and field notes. The results indicated that with the context of Museum Timah Indonesia Pangkalpinang, students could understand angle measurement. Students are more interested and motivated in completing angular measurements so that learning is more meaningful. PMRI can be used as an approach to learning angular measurements in elementary schools.
\end{abstract}

Keywords: Angle; museum timah indonesia; $R M E$

\section{PENDAHULUAN}

Pendidikan merupakan salah satu unsur penting dalam meningkatkan dan mengembangkan Sumber Daya Manusia (SDM). Pendidikan dituntut untuk menciptakan SDM yang cerdas dan mampu bersaing di kehidupan yang akan datang. Pembangunan di masa yang akan datang dapat didukung oleh Pendidikan melalui pengembangan potensi peserta didik, sehingga peserta didik mampu mampu menghadapi dan memecahkan problema kehidupan yang dihadapi (Suhendri, 2015).

Sekolah Dasar merupakan modal awal peserta didik melanjutkan pendidikan ke jenjang sekolah menengah. Pendidikan yang akan menghasilkan peserta didik yang berkualitas dimulai dari sekolah dasar. Salah satu mata pelajaran yang diajarakan sejak pendidikan sekolah dasar adalah matematika. Matematika memiliki peranan yang amat penting dalam kehidupan sehari-hari. Segala 
sesuatu tidak lepas dari matematika bahkan ilmu pengetahuan seperti fisika, kimia, biologi, komputer dan lain sebagainya juga tidak lepas dari peran matematika didalamnya.

Aspek Kompetensi Dasar (KD) yang terdapat dalam pembelajaran matematika di sekolah dasar mulai dari kelas I sampai dengan kelas IV adalah Geometri dan pengukuran. Sudut merupakan konsep dasar yang paling penting dipahami dalam mempelajari geometri (Widyawati \& Putri, 2016). Berdasarkan standar isi yang harus dicapai siswa untuk mata pelajaran matematika di Sekolah Dasar berdasarkan Peraturan Menteri Pendidikan dan Kebudayaan Nomor 21 Tahun 2016 (BNSP, 2016) adalah bilangan asli dan pecahan sederhana, Geometri dan pengukuran sederhana, serta statistika sederhana.

Disekolah dasar, sudut masih sulit dipahami terutama dalam hal pengukuran sudut. Hasil wawancara dengan guru kelas IV SD N 29 Pangkalpinang bahwa materi sudut memang sudah dipelajari oleh siswa di kelas III namun hanya sebatas pengenalan sudut dan jenis-jenis sudut saja. Tapi untuk kelas IV pokok bahasan materi sudut yang sulit dipahami siswa adalah pengukuran sudut dengan busur derajat. Namun saat dilakukan test awal terhadap materi sudut, hanya $23 \%$ siswa yang mengetahui pengertian sudut dan jenisjenis sudut. Sedangkan 77\% siswa tidak mengetahui apa itu sudut apalagi jenisjenis sudut.Dikatakan juga oleh Wijayanti \& Budiono (2015) dalam penelitiannya bahwa masih banyak siswa yang mengalami kesulitan dalam melakukan pengukuran sudut.

Hal yang sama juga diungkapkan oleh Sari, Putri, \& Kesumawati (2015) bahwa konsep pengukuran sudut merupakan hal yang sulit dipahami oleh banyak siswa. Penelitian yang dilakukan oleh Nur'aeni \& Muharram (2016) menyatakan bahwa hambatan siswa dalam mempelajari materi sudut diantaranya mengukur sudut menggunakan busur derajat, keterbatasan konteks yang diajarkan pada saat pertama kali materi pengukuran sudut dipelajari, dan aplikasi konsep sudut dalam kehidupan sehari-hari.

Kurangnya kemampuan pemahaman konsep siswa ini dikarenakan prosedur yang dilakukan dalam pembelajaran sudur hanya sebatas menerangkan materi, memberikan contoh-contoh, kemudian latihan soal-soal (Soedjadi, 2014). Dipertegas oleh Apriani (2018) bahwa pada umumnya, proses pembelajaran matematika yang dilakukan hanya menyajikan masalah, melakukan demonstrasi cara penyelesaian masalah, selanjutnya siswa diminta untuk menyelesaikan latihan soal yang diberikan oleh guru. Oleh karena itu, prosedur pembelajaran dapat diperbaharui agar siswa dapat membangun dan mengontruksi kemampuan dengan mengubah cara siswa belajar dan cara guru mengajar (Tjiptiany, As'ari, \& Muksar, 2016). Menggunakan matematika dalam konteks di luar matematika merupakan salah satu cara meningkatkan pemahaman yang menyeluruh dan bermakna pada pembelajaran matematika (Apriani, Zulkardi, \& Darmawijoyo, 2017). Menurut Widyawati \& Putri (2016) bahwa siswa dapat memahami konsep sudut jika menggunakan sebuah konteks pada suatu pembelajaran sudut.

Konteks erat kaitannya dengan Pendekatan Matematika Realistik Indonesia (PMRI). Karena masalah 
yang diberikan dalam memulai pembelajaran pada PMRI adalah masalah kontekstual yaitu fenomena dan aplikasi yang real terhadap siswa (Ulya, Zulkardi, \& Putri, 2010). Fungsi konteks dalam Pendidikan Matematika Realistik Indonesia (PMRI) dimana konteks sebagai titik awal bagi siswa dalam mengembangkan pengertian matematika dan sekaligus menggunakan konteks tersebut sebagai sumber aplikasi matematika (Zulkardi \& Putri, 2010).

Berbagai penelitian tentang sudut pernah dilakukan oleh peneliti terdahulu agar pembelajaran sudut mudah dipahami dan inovatif diantaranya Saptono, Wahyudi, \& Indarini (2018) menggunakan metode pembelajaran problem posing, Yusnita (2011) menggunakan pembelajaran kontekstual berlatar pondok pesantren, Binangun \& Hakim (2016) menggunakan alat peraga jam sudut, dan Suryana (2016) melalui optimalisasi penguasaan melalui Pendekatan Pembelajaran Berbasis Masalah. Namun belum ada yang menggunakan pembelajaran berbasis wisata edukasi sebagai konteks awal.

Wisata edukasi yang ada di Kepulauan Bangka Belitung adalah Museum Timah Indonesia Pangkalpinang. Di dalam museum terdapat koleksi sejarah penambangan timah di pulau Bangka. Terdapat juga koleksi alat-alat penambangan timah yang tersusun rapi dan terawat. Selain mempelajari sejarah penambangan timah, bisa juga dijadikan pembelajaran mengenai sudut. Atap depan bangunan museum timah juga bisa menunjukkan jenis-jenis sudut apa saja yang dipakai. Memasuki ruang museum disajikan alat-alat penambangan timah yang juga terdapat sudut-sudut yang bisa diamati. Sehingga selain pembelajaran matematika menjadi lebih menarik.
Berbagai hasil penelitian (Zulkardi \& Putri, 2010; Feriana \& Putri, 2016; Bustang, Zulkardi, \& Darmawijoyo, 2013; Marion, Zulkardi, \& Somakim, 2015; Sari, 2017; Widyastuti \& Pujiastuti, 2014; Nugraheni \& Sugiman, 2013; Pitaloka, Susilo, \& Mulyono, 2012; dan Apriani, Zulkardi, \& Darmawijoyo, 2017) menunjukkan bahwa pendekatan pembelajaran matematika realistik cukup efektif untuk meningkatkan pemahaman konseptual siswa dan dapat digunakan untuk meningkatkan kemampuan pemecahan masalah.

PMRI memiliki empat level dalam pembelajaran yaitu (1) level situasional, dimana ini adalah level paling dasar dari pemodelan dimana pengetahuan dan model masih berkembang dalam konteks situasi masalah yang digunakan, (2)level referensial, dimana siswa membuat model untuk menggambarkan situasi konteks (model mengacu pada aktivitas kegiatan pembelajaran), (3)level general, dimana model yang dikembangkan siswa sudah mengarah pada pencarian solusi matematis (model menghubungkan pada kegiatan matematika, dan (4)level formal, tahap perumusan dan penegasan konsep matematika yang dibangun oleh siswa, dimana tidak bergantung pada dukungan model lagi (Feriana \& Putri, 2016).

Tujuan penelitian ini adalah untuk mengetahui peran konteks Museum Timah Indonesia Pangkalpinang sebagai alternatif pembelajaran materi sudut. PMRI merupakan titik awal penentuan konteks. Diharapkan siswa dapat memahami konsep sudut dan pembelajaran menjadi lebih menarik serta memotivasi siswa dalam mempelajari materi sudut. 
DOI: https://doi.org/10.24127/ajpm.v8i3.2276

\section{METODE PENELITIAN}

Penelitian ini menggunakan metode design research dengan tujuan mengembangkan lintasan belajar materi sudut menggunakan peran konteks Museum Timah Indonesia Pangkalpinang (Gravemeijer \& Van Eerde, 2009).Subjek penelitian adalah siswa kelas IV SD N 29 Pangkalpinang.

Tiga tahapan pada Design research yakni preparing for the experiment, the design experiment (the pilot experiment), restrospective analysis.

Tahap pertama, preparing for the experiment. Pada tahap ini, dilakukan adalah desain awal Lembar Kerja Peserta Didik (LKPD). Desain awal ini berfungsi untuk mengimplementasikan ide-ide awal yang dikembangkan dari kajian literatur dan karakteristik siswa sebelum dikembangkan melalui desain aktivitas-aktivitas pembelajaran.

Tahap kedua, the pilot experiment. Pada tahap ini lintasan belajar yang telah didesain diujicobakan pada small group sebanyak 6 orang yang dipilih berdasarkan tingkat kemampuan yaitu 2 orang siswa dengan kemampuan tinggi, 2 orang siswa dengan kemampuan sedang, dan 2 orang siswa dengan kemampuan rendah.

Tahap ketiga, restrospective analysis. Data yang diperoleh dari tahap the pilot experiment dianalisis untuk mengembangkan desain pada aktivitas pembelajaran sehingga bisa digunakan ke tahap selanjutnya yaitu teaching experiment.

Data penelitian diperoleh dari hasil kerja kelompok siswa, hasil tes, wawancara siswa dan guru, serta catatan lapangan yang terjadi. Hasil kerja kelompok siswa diperoleh dari hasil LKPD yang diberikan untuk mendapatkan informasi apakah lintasan belajar yang didesain melalui aktivitasaktivitas yang ada di LKPD dapat dilakukan dengan baik serta dapat mengungkapkan ide dan gagasan siswa di dalam kelas. Tes dilakukan adalah pre test dan post test dengan tujuan untuk melihat apakah ada peningkatan pengetahuan yang terjadi setelah dilakukan berbagai aktivitas yang diberikan. Wawancara siswa dan guru dilakukan untuk mendapatkan data mengenai pendapat subjek terhadap proses pembelajaran, kelebihan dan kekurangan lintasan belajar yang didedain pada kelas subjek. Catatan lapangan diperoleh dari hasil rekaman video yang dilakukan untuk mendukung hasil LKPD yang dilakukan siswa.

Adapun teknik analisis data dilakukan secara kualitatif dengan memperhatikan hasil pengumpulan data yang telah dilakukan. Analisis data dengan menganalisis hasil tes tertulis siswa dan membandingkan hasil pengamatan selama proses pembelajaran. Lintasan belajar yang didesain dibandingkan dengan proses pembelajaran sehingga dapat dilakukan penyelidikan dan perbandingan antara catatan lapangan dengan dokumendokumen lain yang telah dikumpulkan.

\section{HASIL PENELITIAN DAN PEMBAHASAN}

Museum Timah Indonesia Pangkalpinang sebagai wisata edukasi dipilih sebagai konteks dalam penelitian ini. Selain memberikan edukasi tentang sejarah pertimahan di Bangka. Alat-alat penambangan yang ada di dalam museum juga dijadikan sebagai alat bantu dalam memperkenalkan sudut. Penelitian ini dilakukan dalam 3 kali pertemuan. Dengan dugaan lintasan belajar yaiu : (1) memahami pengertian sudut, (2) memahami sudut dalam kehidupan sehari-hari, dan 
menentukan besar sudut menggunakan busur derajat.

Pada pertemuan pertama, atap museum timah disajikan sebagai permasalahan awal. Dilakukan kepada 6 orang siswa (small group) yang dipilih berdasarkan tingkat kemampuan yaitu 2 orang siswa dengan kemampuan tinggi, 2 orang siswa dengan kemampuan sedang, dan 2 orang siswa dengan kemampuan rendah. Siswa dibagi menjadi dua kelompok masing-masing terdiri dari 3 orang dengan tingkat kemampuan berbeda-beda. Guru model memberikan informasi mengenai Lembar Kerja Peserta Didik yang akan dibagikan. Pada LKPD pertemuan pertama, diberikan informasi mengenai sejarah Museum Timah Indonesia Pangkalpinang. Pada LKPD ini, siswa diinstruksikan untuk mengamati atap Museum Timah Indonesia Pangkalpinang. Kemudian siswa diminta untuk menunjukkan bagian atap yang membentuk sebuah sudut. Dengan arahan dan bantuan peneliti, siswa membayangkan tendangan sudut yang ada dalam pertandingan sepak bola. Tujuannya untuk mengarahkan siswa memahami bagian yang dinamakan sudut. Hasil jawaban siswa tersaji pada Gambar 1.

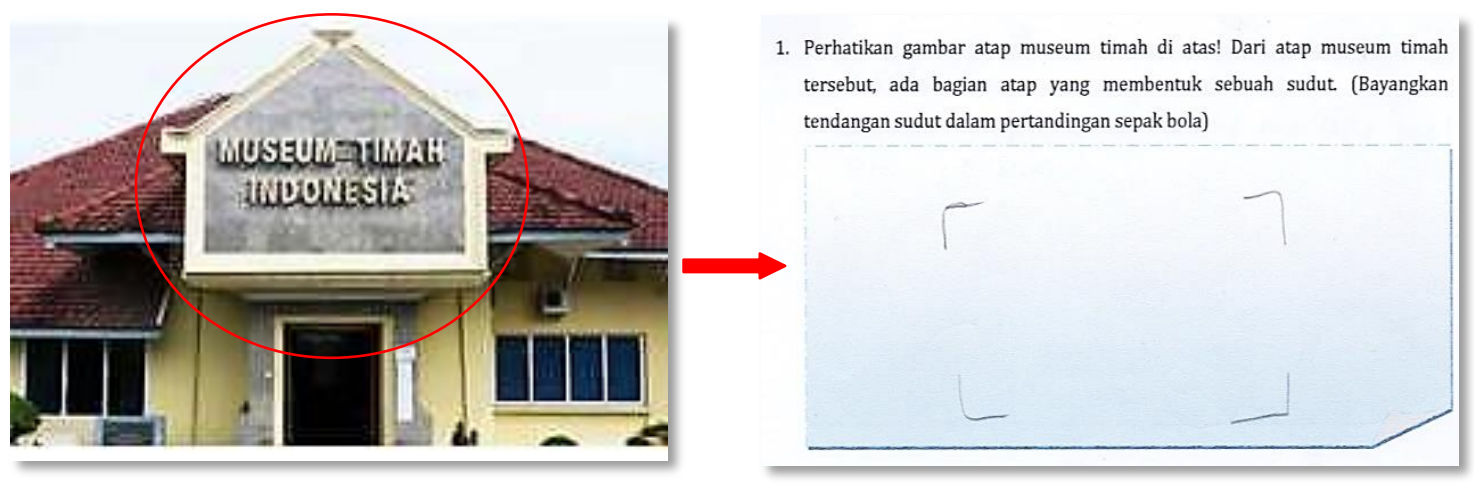

Gambar 1. Jawaban siswa nomor 1 pada LKPD 1

Selanjutnya, siswa masih diminta untuk membayangkan tetapi untuk posisi bola pada tendangan sudut. Lalu siswa diminta untuk membuat tanda pada atap Museum Timah Indonesia
Pangkalpinang yang sesuai dengan posisi bola pada tendangan sudut tersebut. Hal ini bertujuan agar siswa mengetahui posisi titik sudut. Hasil jawaban siswa tersaji pada Gambar 2.

2. Dimanakah letak bola pada tendangan sudut jika kalian lihat pada atap museum timah diatas. Berikan tanda pada gambar yang telah kalian buat!

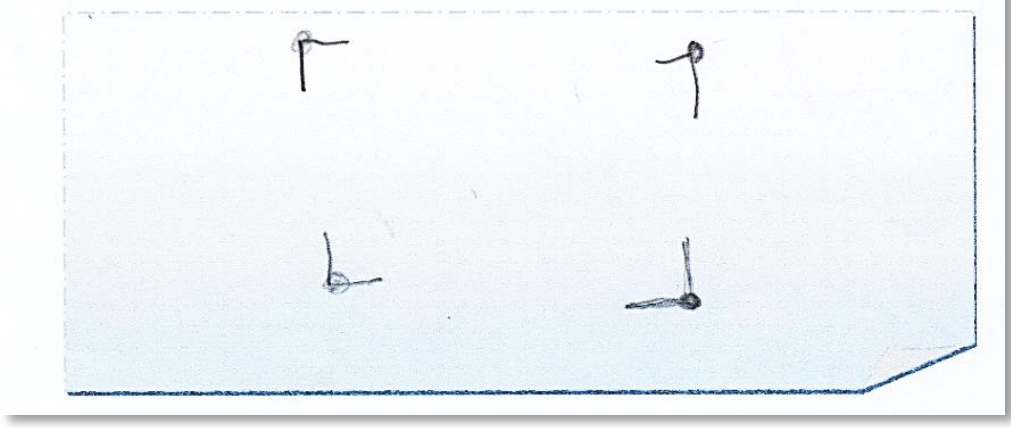

Gambar 2. Jawaban siswa nomor 2 pada LKPD 1 
DOI: https://doi.org/10.24127/ajpm.v8i3.2276

Gambar 2 menunjukkan hasil jawaban siswa dalam membuat tanda sebagai posisi bola jika digambarkan pada atap Museum Timah Indonesia Pangkalpinang. Setelah menentukan posisi bola, siswa diminta untuk menentukan banyaknya garis tepi yang ada di pojok atap museum yang menggambarkan sebuah sudut. Tujuannya agar siswa mengetahui bahwa garis tepi tersebut adalah kakikaki sudut. Hasil jawaban siswa tersaji pada Gambar 3.

3. Ada berapa garis tepi di pojok atap museum timah yang menggambarkan sudut pada gambar yang telah kalian buat?

2

Gambar 3. Jawaban siswa no 3 pada LKPD 1

Gambar 3 menunjukkan hasil jawaban siswa dalam menentukan banyaknya garis tepi. Sehingga didapatkan jawaban bahwa garis tepi atap museum yang menunjukkan sudut adalah dua. Setelah siswa menjawab pertanya 1 sampai 3 pada LKPD 1, siswa diminta untuk menarik kesimpulan pengertian sudut dengan pertanyaan yang diajukan adalah "Jika garis-garis tepi tersebut adalah kaki sudut dan posisi bola adalah titik sudut? Dapatkah kalian menyimpulkan, apakah itu sudut". Tujuannya agar siswa mengetahui pengertian sudut. Hasil jawaban siswa tersaji pada Gambar 4.

4. Jika garis-garis tersebut adalah kaki sudut. Dan posisi bola adalah titik sudut? Dapatkah kalian menyimpulkan, apakah itu sudut?

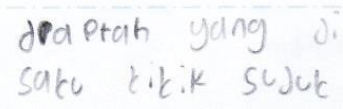

Gambar 4. Jawaban siswa no 4 pada LKPD 1

Gambar 4 menunjukkan hasil jawaban siswa dalam memberikan kesimpulan, yaitu pengertian sudut. Setelah menyelesaikan semua pertanyaan pada LKPD 1, perwakilan kelompok diminta untuk memaparkan hasil jawaban kelompok mereka. Kelompok lain diminta untuk memperhatikan. Jika kelompok lain memiliki jawaban berbeda, maka diperbolehkan untuk mengutarakan hasil kelompoknya.

Pada pertemuan kedua, dilakukan kunjungan ke Museum Timah Indonesia Pangkalpinang. Sebelum berangkat, dilakukan sesi tanya jawab mengenai materi pengertian sudut yang telah dipelajari sebelumnya untuk memantapkan konsep tentang pengertian sudut. Selanjutnya diberikan informasi tentang kegiatan yang akan dilakukan pada pertemuan kedua ini. Siswa tetap dikondisikan berkelompok. Sesampainya di museum. Siswa dipandu oleh pemandu museum, siswa diperkenalkan alat-alat yang ada di museum. Tugas siswa dalam pertemuan kali ini bukan hanya diperkenalkan dengan alat dan fungsinya tetapi juga menuliskan nama alat yang ada 
DOI: https://doi.org/10.24127/ajpm.v8i3.2276

dimuseum timah beserta fungsinya yang ada unsur sudut dialat tersebut pada

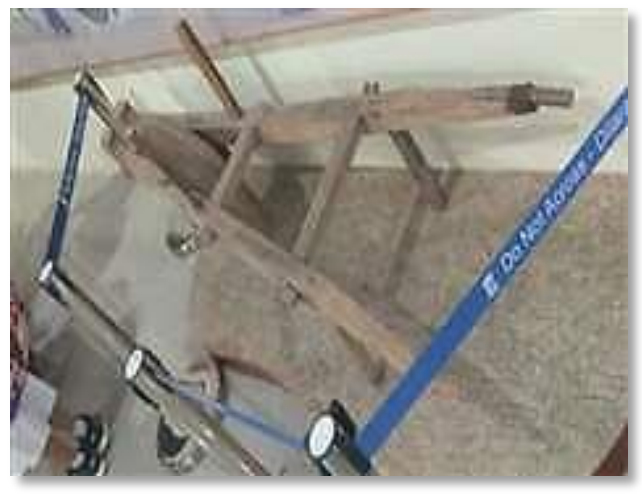

LKPD 2. Hasil jawaban siswa tersaji pada Gambar 5.

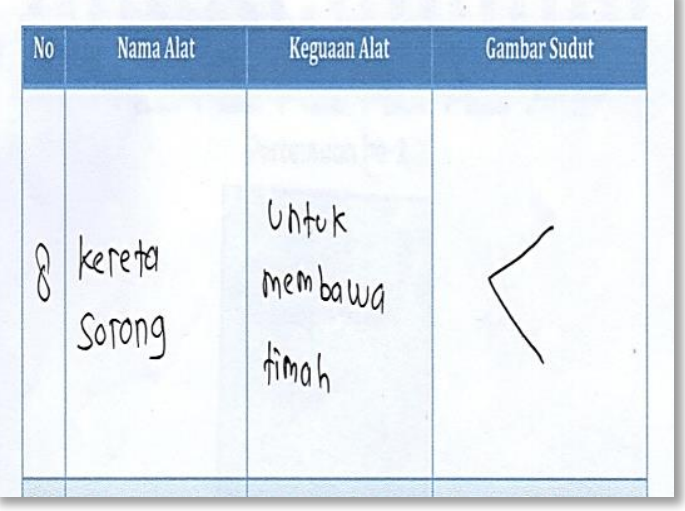

Gambar 5. Jawaban siswa pada LKPD 2

Gambar 5 menunjukkan hasil jawaban siswa yaitu nama alat, fungsi dan gambar sudut dalam alat penambangan timah.

Pada pertemuan ketiga, siswa tetap duduk berkelompok. Di awal pembelajaran, dilakukan tanya jawab mengenai alat-alat penambangan timah hasil kunjungan museum pada pertemuan sebelumnya. Selanjutnya diberikan informasi tentang materi yang akan dipelajari pada pertemuan ketiga ini. Selanjutnya, dibagikan LKPD 3 yang memuat tentang menentukan besar sudut menggunakan busur berwarna dilanjutkan dengan busur derajat. Permasalahan yang ada di LKPD 3 tersaji pada Gambar 6.

Pertemuan sebelumnya, kita sudah mengunjungi Museum Timah Indonesia, Pangkalpinang. Banyak pelajaran yang kita dapatkan dengan mengunjungi museum timah tersebut. Selain kita mengetahui alat-alat penambangan timah dan kegunaannya, kita juga mempelajari tentang sudut pada alat-alat tersebut. Hampir semua alat penambangan timah ada unsur sudut di dalamnya. Sekarang, untuk mengingatkan kalian tentang alat penambangan timah yang telah kalian amati. Perhatikan gambar dibawah ini! Berikan tanda silang $(\mathrm{X})$ pada gambar yang menunjukkan barang-barang yang ada di dalam Museum Timah Indonesia, Pangkalpinang.
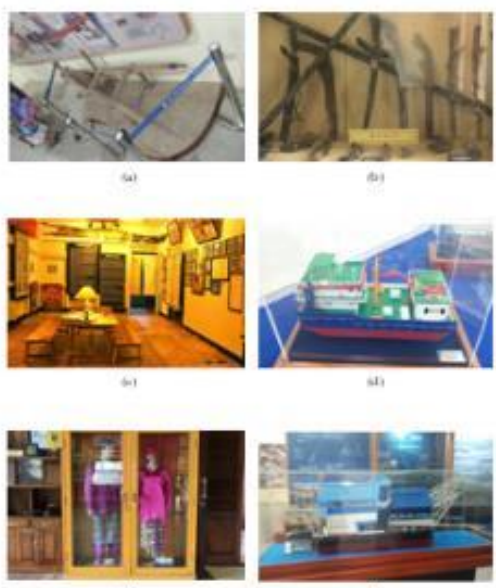

Gambar 6. Permasalahan pada LKPD 3 
Gambar 6 menunjukkan permasalahan awal yan diberikan pada LKPD 3. Siswa diminta untuk memilih alat yang ada di museum pada pilihan gambar yang diberikan. Tujuannya adalah untuk mengetahui pegetahuan sebelumnya saat kunjungan ke museum.
Selanjutnya siswa diminta untuk memilih satu saja alat yang telah dipilih tersebut. Lalu diminta untuk menggambarkan unsur sudut yang ada pada alat yang dipilih. Hasil jawaban siswa tersaji pada gambar 7 .

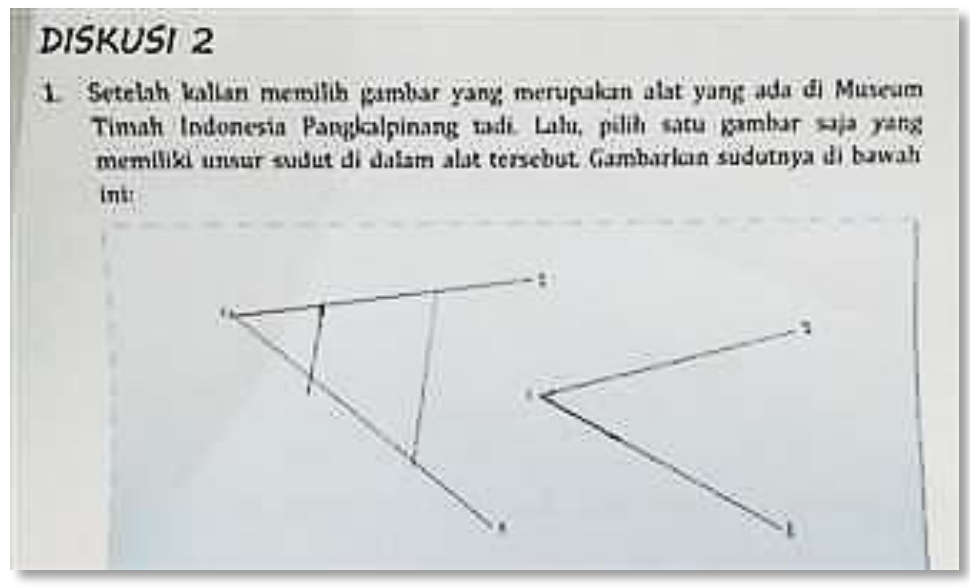

Gambar 7. Jawaban soal nomor 1 pada LKPD 3

Gambar 7 menunjukkan gambar sudut yang ada pada alat yang telah dipilih. Selanjutnya, siswa diminta membentuk sudut yang telah dibuat menggunakan lidi yang telah ditentukan. Lalu lidi-lidi tersebut direkatkan. Hasil jawaban siswa tersaji pada gambar 8 berikut:

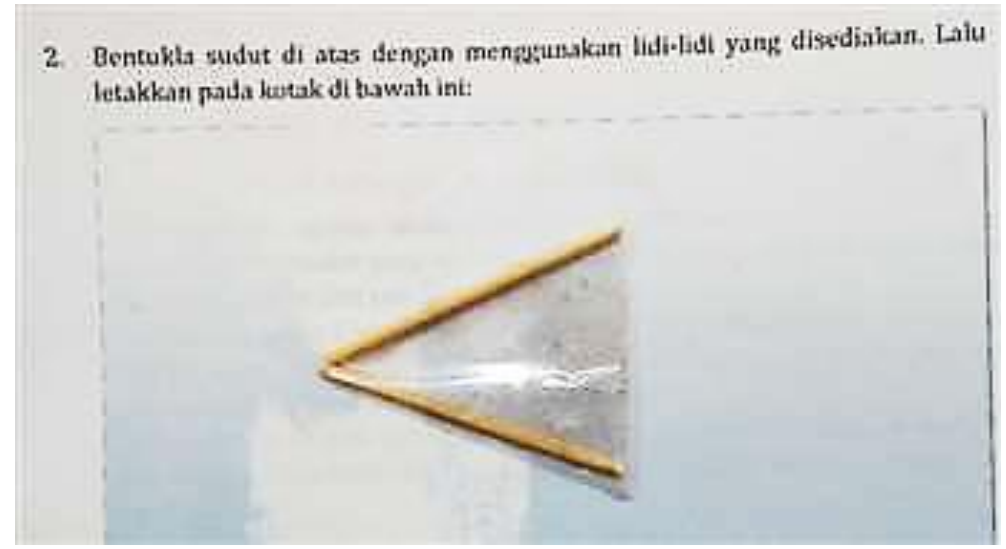

Gambar 8. Jawaban soal nomor 2 pada LKPD 3

Gambar 8 menunjukkan hasil bentukan sudut dari lidi yang direkatkan. Aktivitas selanjutnya adalah siswa diminta mengikuti instruksi yang ada pada LKPD 3. Lalu siswa diarahkan menemukan sendiri konsep dalam menentukan besar sudut. Dimana media yang digunakan adalah busur berwarna. Instruksi pada aktivitas tersaji pada Gambar 9. 
DOI: https://doi.org/10.24127/ajpm.v8i3.2276

\section{INTRUKSI}

Bacalah dengan cermat dan teliti!

1. Masing-masing kelompok diberikan busur berwarna dengan 18 potong kertas berwarna dibusur tersebut, seperti gambar berikut:

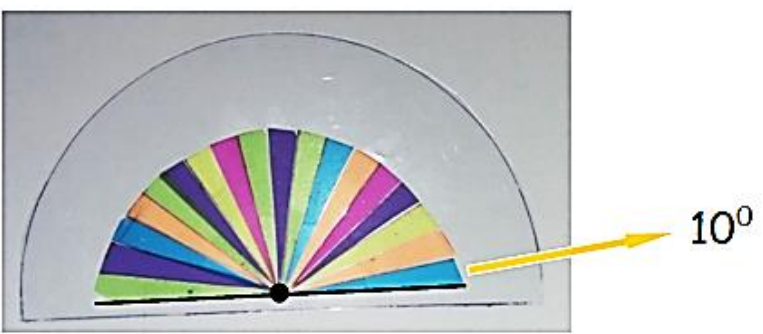

2. Satu potongan kertas, menunjukkan bahwa besar sudutnya adalah 10 derajat $\left(10^{\circ}\right)$.

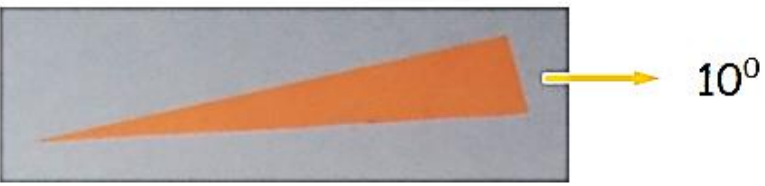

Gambar 9. Informasi yang diberikan pada aktivitas LKPD 3

Gambar 9 menunjukkan informasi yang ada pada busur berwarna yang dibagikan kepada siswa. Dimana terdapat 18 potong kertas warna. Setiap potong kertas bernilai $10^{\circ}$. Selanjutnya, untuk menentukan besar sudut dilakukan kegiatan mengikuti langkahlangkah yang ada pada LKPD. Langkah-langkah pengerjaannya tersaji pada Gambar 10.

\section{MENENTUKAN BESAR SUDUT}

lkuti langkah-langkah pengerjaan di bawah ini:

1. Letakkan lidi yang telah dibuat di atas busur berwarna.

2. Himpitkan titik sudut yang ada pada lidi ke titik hitam yang ada pada busur berwarna dengan titik sudut yang ada pada lidi.

3. Pilihlah kaki sudut 1 lalu himpitkan garis hitam yang ada pada busur berwarna.

4. Setelah tepat, kaki sudut yang lainnya (kaki sudut 2) akan menempati tepi potongan kertas berwarna yang ada pada busur.

5. Hitung berapa banyak potongan kertas warna yang ada dari kaki sudut 1 ke kaki sudut 2 . Tulis jawaban yang kalian dapatkan pada kotak di bawah ini:

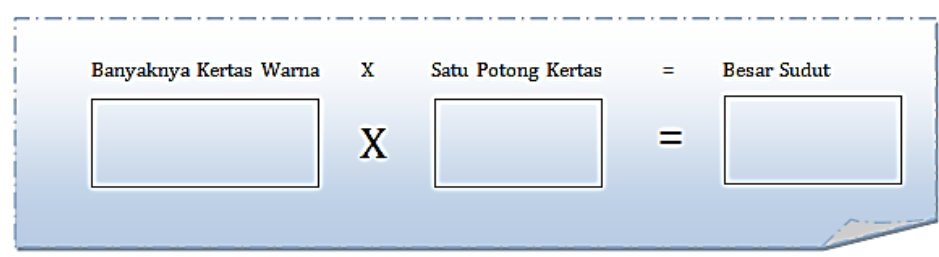

Gambar 10. Langkah menentukan besar sudut dengan busur berwarna

Gambar $\quad 10 \quad$ menunjukkan langkah-langkah yang harus diikuti dalam menentukan besar sudut dengan busur berwarna. Dimana lidi yang telah dibuat tadi diletakkan diatas busur berwarna. Dengan ketentukan titik 
DOI: https://doi.org/10.24127/ajpm.v8i3.2276

sudut pada lidi harus berhimpit dengan lingkar hitam dan satu kaki sudut harus berhimpit dengan garis hitam yang terletak di kanan atau kiri titik hitam. Setelah itu, siswa diminta menghitung berapa banyak potongan warna yang ada di dalam lidi tersebut. Lalu menuliskan pada kotak jawaban yang telah disediakan. Aktivitas yang dilakukan oleh siswa tersaji pada Gambar 11.

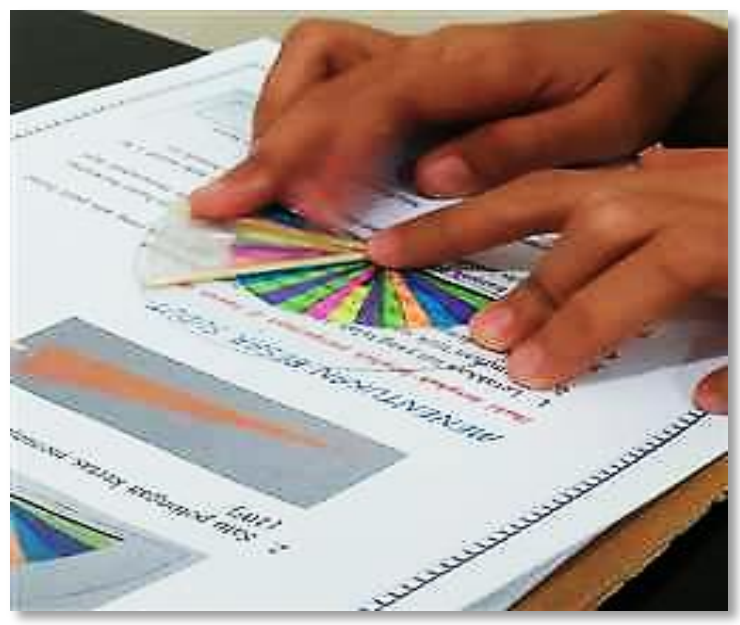

Gamabr 11. Aktivitas siswa menggunakan busur warna.

Setelah melakukan pengukuran tersebut. Siswa diminta untuk menentukan besar sudut menggunakan busur derajat. Dengan instruksi yang diberikan oleh guru dan memperhatikan instruksi selanjutnya yang ada pada LKPD. Siswa menentukan besar sudut menggunakan busur derajat. Instruksi pada LKPD 3 dan aktivitas siswa tersaji pada Gambar 12.

1. Titik hitam pada busur berwarna adalah titik sudut. Perhatikan busur derajat yang diberikan. Dengan arahan guru, kalian akan mengetahui. Titik hitam yang ada di busur berwarna sama halnya dengan titik apa pada busur derajat.

2. Begitu juga dengan garis hitam pada busur berwarna. Garis hitam pada busur berwarna adalah kaki sudut. Perhatikan arahan guru agar kalian akan mengetahui kaki sudut pada busur derajat.

3. Dengan langkah menentukan besar sudut menggunakan busur berwarna di atas. Ukuran sudut yang telah dibuat dengan lidi menggunakan busur derajat.

Gambar 12. Instruksi dan aktivitas mengukur sudur dengan busur derajat pada LKPD 3.

Setelah dilakukan berbagai aktivitas tersebut, pada pertemuan selanjutnya diberikan tes evaluasi. Diperoleh nilai hasil tes evaluasi yang dilakukan. Dari 6 orang siswa diperoleh rata-rata 75,8 dengan nilai tertinggi 95 dan nilai terendah 63. Dari hasil tersebut didapat bahwa hasil tes evaluasi dikategorikan baik.

Pada penelitian ini, karakteristik PMRI menjadi dasar pada setiap aktivitas. Aktivitas belajar yang didesain juga mencerminkan lima karakteristik PMRI (Zulkardi \& Putri, 
2010) yaitu: Pertama, menggunakan masalah kontekstual. Kegiatan dimulai dengan permasalahan yang ada di sekitar siswa. Konteks yang dipilih adalah publik dimana situasi terkait dengan kehidupan dan aktivitas masyarakat sekitar siswa tersebut tinggal. Pada penelitian ini adalah Museum Timah Indonesia Pangkalpinang. Selain dekat tempat tingga siswa. Museum juga menjelaskan tentang tambang timah yang banyak dilakukan disekitar siswa. Kedua, penggunaan model untuk matematisasi progresif. Museum Timah Indonesia Pangkalpinang dengan berbagai alat penambangan timah digunakan sebagai contoh penggunaan sudut dalam kehidupan sehari-hari. Selanjutnya digunakan busur berwarna sebagai alat awal dalam memahami pengukuran sudut. Ketiga, pemanfaatan hasil kontribusi siswa, diberikan kebebasan kepada siswa dalam proses pembelajaran dalam menentukan setiap permasalahan yang ada pada setiap aktivitas. Keempat, interaktivitas, interaksi terjadi antara guru dan siswa maupun siswa dan siswa dalam diskusi. Kelima, keterkaitan, materi sudut ini terintegrasi dengan topik wisata edukasi Museum Timah Indonesia Pangkalpinang dan busur berwarna sebagai alat bantu memahami pengukuran sudut.

Hasil Penelitian ini bersesuaian dengan penelitian Putri (2011) yang menjelaskan bahwa PMRI menggiring siswa memahami konsep matematika. Dan juga melengkapi hasil-hasil penelitian sebelumnya khusunya mengenai desain pembelajaran berbasis PMRI pada materi pengukuran sudut.

Penelitian ini juga menunjukkan bahwa konteks Museum Timah Indonesia Pangkalpinang mempunyai peran dalam meningkatkan kemampuan pemahaman konsep sudut siswasehingga dapat menjadi bahan pertimbangan guru dalam pembelajaran sudut. Siswa sekolah dasar masih pada tahapan operasional konkret membutuhkan pembelajaran secara kontekstual. Oleh karena itu, konteks Museum Timah Indonesia Pangkalpinang ini dapat digunakan dalam pembelajran sudut.

\section{KESIMPULAN DAN SARAN}

Berdasarkan hasil penelitian ini, dapat disimpulkan bahwa Museum Timah Indonesia Pangkalpinang bisa dijadikan alternatif konteks pada pembelajaran materi sudut siswa kelas IV SD. Museum Timah Indonesia Pangkalpinang dengan PMRI dapat mendukung siswa dalam memahami materi sudut serta membuat siswa lebih tertarik dan termotivasi untuk belajar. Terlihat dari hasil tes evaluasi akhir siswa yang mencapai rata-rata 75,8 dengan kategori baik.

Berdasarkan temuan dalam penelitian ini, maka beberapa saran yang dikemukakan adalah konteks wisata edukasi dalam penelitian ini Museum Timah Indonesia Pangkalpinang dapat digunakan oleh guru sebagai alternatif pembelajaran materi pengukuran sudut untuk meningkatkan pemahaman konsep siswa. Sedangkan bagi peneliti selanjutnya dapat melihat efektifitas pembelajaran dengan menggunakan konteks wisata edukasi dan juga pembelajaran matematika sebaiknya menggunakan metode yang inovatif seperti penggunaan PMRI dalam pembelajaran dan untuk membantu siswa memahami konsep matematika sebaiknya menggunakan alat bantu yang bisa disesuaikan dengan materi pelajaran. 
DOI: https://doi.org/10.24127/ajpm.v8i3.2276

\section{DAFTAR PUSTAKA}

Apriani, F. (2018). Kesalahan Mahasiswa Calon Guru SD dalam Menyelesaikan Soal Pemecahan Masalah Matematika. Journal of Mathematics Science and Education, 1(1), 102-117.

Apriani, F., Zulkardi, \& Darmawijoyo. (2017). Pendekatan PMRI Membantu Siswa Berpikir Kritis pada Materi Sistem Persamaan Linear di Kelas X. Seminar Nasional dan Workshop Matematika dan Pendidikan Matematika "Menjawab Tantangan Abad 21 Melalui 4C's dengan PMR" STKIP PGRI Sumatera Barat, 111-122. Padang: STKIP PGRI Sumatera Barat Press.

Binangun, H., \& Hakim, A. R. (2016). Pengaruh penggunaan alat peraga jam sudut terhadap hasil belajar matematika. JKPM (Jurnal Kajian Pendidikan Matematika), 1(2), 204-214.

BNSP. (2016). Standar Isi Pendidikan Dasar dan Menengah. Diambil 30 Juni 2019 dari BNSP indonesia: http://bsnp-indonesia.org.

Bustang, B., Zulkardi, Z., Darmawijoyo, D., Dolk, M. L. A. M., \& van Eerde, H. A. A. (2013). Developing a local instruction theory for learning the concept of angle through visual field activities and spatial representations. International Education Studies, 6(8), 58-70.

Feriana, O., \& Putri, R. I. I. (2016). Desain Pembelajaran Volume Kubus dan Balok Menggunakan Filling dan Packing di Kelas V. Jurnal Kependidikan: Penelitian Inovasi Pembelajaran, 46(2), 149163.
Gravemeijer, K. \& Van Eerde, D. (2009). Design Research as a Means for Building a Knowledge Base for Teacher and Teaching in Mathematics Education. The Elementary School Journal, 109(5), 510-524.

Marion, M., Zulkardi, Z., \& Somakim, S. (2015). Desain pembelajaran pola bilangan menggunakan model jaring laba-laba di SMP. Jurnal Kependidikan: Penelitian Inovasi Pembelajaran, 45(1), 4461.

Nugraheni, E. A., \& Sugiman, S. (2013). Pengaruh pendekatan PMRI terhadap aktivitas dan pemahaman konsep matematika siswa SMP. PYTHAGORAS: Jurnal Pendidikan Matematika, 8(1), 101-108.

Nur'aeni, E., \& Muharram, R. (2016). Desain Didaktis Konsep Mengukur Sudut di Kelas V Sekolah Dasar. Seminar Nasional Matematika Dan Pendidikan Matematika UNY, 209-216. Yogyakarta: UNY.

Pitaloka, Y. D., Susilo, B. E., \& Mulyono, M. (2012). Keefektifan Model Pembelajaran Matematika Realistik Indonesia terhadap Kemampuan Pemahaman Konsep Matematika. Unnes Journal of Mathematics Education, 1(2).

Putri, R. I. (2011). Professional Development of Mathematics Primary School Teacher in Indonesia Using Lesson Study and Realistic Mathematics Education Approach. Lymasol, Cyprus: Proceeding of International Congress for school Effectiveness and Improvement (ICSEI). 
Saptono, B., Wahyudi, W., \& Indarini, E. (2018). Penerapan Motode Pembelajaran Problem Posing untuk Meningkatkan Kemampuan Pemecahan Masalah Pengukuran Sudut dengan Busur Derajat Siswa Kelas 4 SDN Barukan 02. Kalam Cendekia PGSD Kebumen, 6(4.1), 30-36.

Sari, P. (2017). Pemahaman konsep matematika siswa pada materi besar sudut melalui pendekatan PMRI. Jurnal Gantang, 2(1), 4150.

Sari, P., Putri, R. I., \& Kesumawati, N. (2015). Desain Pembelajaran Materi Pengukuran Sudut dengan Pendekatan PMRI untuk Kelas VI. Jurnal Numeracy, 33-42.

Soedjadi, R. (2014). Inti Dasar-Dasar Pendidikan Matematika Realistik Indonesia. Jurnal Pendidikan Matematika, 1(2), 1-10.

Suhendri, H. (2015). Pengaruh metode pembelajaran problem solving terhadap hasil belajar matematika ditinjau dari kemandirian belajar. Formatif: Jurnal Ilmiah Pendidikan MIPA, 3(2).

Suryana, M. F. (2016). Optimalisasi Penguasaan Materi Garis dan Sudut Melalui Pendekatan Pembelajaran Berbasis Masalah di SMP. Manajemen Pendidikan, 10(1), 141-153.

Tjiptiany, E. N., As'ari, A. R., \& Muksar, M. (2016). Pengembangan Modul Pembelajaran Matematika dengan Pendekatan Inkuiri untuk Membantu Siswa SMA Kelas X dalam Memahami Materi Peluang. Jurnal Pendidikan: Teori, Penelitian, dan
Pengembangan, 1(10), 19381942.

Ulya, Zulkardi, Z., \& Ilma, R. (2010). Desain Bahan Ajar Penjumlahan Pecahan Berbasispendidikan Matematika Realistik Indonesia (PMRI) Untuk Siswa Kelas IV Sekolah Dasar Negeri 23 Indralaya. Jurnal Pendidikan Matematika, 4(2), 86-96.

Widyawati, W., \& Putri, R. I. I. (2016). Desain Pembelajaran Sudut Menggunakan Konteks Rumah Limas di Kelas VII. JINoP (Jurnal Inovasi Pembelajaran), 2(2), 437-448.

Widyastuti, N. S., \& Pujiastuti, P. (2014). Pengaruh pendidikan matematika realistik indonesia (PMRI) terhadap pemahaman konsep dan berpikir logis siswa. Jurnal Prima Edukasia, 2(2), 183193.

Wijayanti, I. L., \& Budiyono. (2015). Pengaruh Penggunaan Media Jam Terhadap Hasil Belajar Siswa Materi Pengukuran Sudut Siswa Sekolah Dasar. Jurnal Pendidikan Guru Sekolah Dasar, 861-870.

Yusnita, E. (2011). Pembelajaran Kontekstual berlatar pondok pesantren pada materi garis dan sudut di kelas VII MTS. In Prosiding Seminar Nasional Matematika Dan Pendidikan Matematika UNY.

Zulkardi, \& Putri, R. I. (2010). Pengembangan Blog Support untuk Membantu Siswa dan Guru Matematika Indonesia Belajar Pendidikan Matematika Realistik Indonesia (PMRI). Jurnal Inovasi Perekayasa Pendidikan , 1-2. 